debattform forbauser oss. Han presiserer i sitt siste innlegg at han punktvis vil ta opp de punkter vi tok opp i forrige innlegg, men han hopper rett og slett over punktet hvor vi tilbakeviste hans påstander om at vi har vært lettferdige i omgang med tall. Her synes vi han kunne ha innrømmet sin feil.

Det faktum at det i Litauen ikke var mulighet for økonomisk kompensasjon etter nakkeslengskade, var et premiss. Hensikten med selve undersøkelsen har jo selvsagt vært noe helt annet, for eksempel å studere langtidsprognosen. Skal man undersøke prognosen ved et sykdomsbilde, er bud nummer én at man må være sikker på at deltakerne virkelig har denne spesielle sykdommen. I den første, skjellsettende Litauen-undersøkelsen kan man ikke vite hvor mange som hadde plager ved starten og eventuelt $i$ hvilken grad. Utgangspunktet for undersøkelsene var galt, og resultatene deretter.

Stovner påsto tidlig i diskusjonen at det var en fordel med mannsovervekt i Litauen-studien. Vi tilretteviste ham. Nå hevder han igjen, og med stor styrke, at det ikke er noe negativt med en slik skjevfordeling med hensyn til kjønn, siden den skadelidte i høyesterettsdommen var en mann. Og hvis det hadde vært en kvinne? Vi har nok ikke vært klar over at Litauen-undersøkelsen har vært intendert som en mannsstudie. Den midlere kvinneovervekt i nakkeslengsmaterialer, generelt, er betydelig. I Litauen-studien var mannsovervekten markant. Dette er en skavank som bidrar til å gjøre Litauen-studien ubrukbar som generell informasjonskilde ved nakkeslengskade.

Vi skal ha vært uklare og lite stringente («lite eksplisitt») i våre utsagn. Er dette en forblommet måte å komme seg unna ubehagelige fakta på? Stovner argumenterer jo faktisk mot våre utsagn. Betyr dette at han sier seg uenig i utsagn som han kan ha misforstått? Skal Stovners påstand om upresise utsagn stå til troende, er det minste han kan gjøre å komme med eksempler på tvetydige uttalelser fra vår side. Ellers henger dette i luften.

Ottar Sjaastad

ellhed@online.no

Johan Petter Hesselberg
Ottar Sjaastad (f. 1928) er dr.med., spesialist i nevrologi, pensjonert overlege og professor.

Ingen oppgitte interessekonflikter.

Johan Petter Hesselberg (f. 1932) er spesialist i nevrologi og pensjonert overlege.

Ingen oppgitte interessekonflikter.

\section{Re: Ikke spør legen}

Lederskribenten skriver at «Den viktigste risikofaktoren for å bli utsatt for overdiagnostisering og overbehandling er å oppsøke helsevesenet». Jeg skjønner hva han vil frem til, men dette er en måte å omtale statistikk på som jeg ikke tror er heldig for å få frem poenget. Det er forskjell på kausalitet og korrelasjon. Jeg kan med liknende bruk av statistikk si at «Den viktigste risikofaktoren for å bli drept i bilulykke er å ta førerkort». Eller: «Den viktigste risikofaktoren for å dø i husbrann er å eie eget hus.» Det betyr ikke at dette har noen relevans med henblikk på å advare folk mot å ta førerkort eller å kjøpe seg eiendom. Tilsvarende bruk av statistikk er etter mitt skjønn heller ikke relevant i denne sammenhengen. Jeg får ikke spesielt lyst til å lese artikkelen videre når jeg ser en slik tullete innledning. Når jeg likevel velger å gjøre det, viser det seg å være en nokså bra artikkel. PS: Den viktigste risikofaktoren for å få kronisk musearm er forresten å bruke PC. Just saying.

\section{Rune Tveiterås}

rune.tveiteras@gmail.com

Rune Tveiterås (f. 1983) jobber som adjunkt i grunnskolen og er utdannet personlig trener ved Norges idrettshøgskole.

Ingen oppgitte interessekonflikter. 